\title{
Evaluation of two eco-friendly botanical extracts on fruit rot pathogens of orange (Citrus sinesis (L.) Osbeck)
}

\author{
Hiệu quả của hai loại dịch trích thực vật đối với các tác nhân gây thối trái cam \\ (Citrus sinensis (L.) Osbeck)
}

LE, Thanh Toan*; VO, Trong Ky; NGUYEN, Huy Hoang

College of Agriculture and Applied Biology, Can Tho University, 3/2 Str., Can Tho city, Viet Nam

\begin{abstract}
Fruit rot caused by Aspergillus niger and Colletotrichum sp. could cause rapid and severe damage on orange fruits. Current control method of orange fruits is mainly applied by usage of harmful pesticides, leading to chemical residues on fruits, environmental pollution and human poisoning. One of alternative methods of reducing pesticides is to use botanical extracts. This study was conducted to evaluate the in vivo antifungal efficacy of aqueous extracts from the leaves of neem and basket plants against $A$. niger and Colletotrichum sp. Orange fruits artificially inoculated by fruit rot pathogens were immersed into leaf extracts of $6 \%(\mathrm{w} / \mathrm{v})$ neem or basket plants for $30 \mathrm{~s}$, and kept for 11 days to record lesion length at room temperature. Orange fruits immersed into sterile distilled water were used as the control treatment. The results showed that at 11 days after inoculation, extracts of neem and basket plants significantly reduced the Aspergillus rot lesions by 109.08 and $124.00 \mathrm{~mm}$, respectively. In addition, anthracnose lesions on orange fruits were statistically inhibited by treatments of neem and basket plants, with the average lesion diameters approximately 160.00 and $154.75 \mathrm{~mm}$, respectively, at day 11 of the conducting experiment. The results of this study showed that leaf extracts of neem and basket plant at the concentration of $6 \%$ could be used as a natural alternative to control the in vivo growth of rot pathogens of orange fruits. These extracts have a bright future in modern plant protection to replace conventional synthetic pesticides in agro-ecosystem.
\end{abstract}

\begin{abstract}
Thối trái bởi Aspergillus niger và Colletotrichum sp. gây ra các thiệt hại nghiêm trọng trên cam. Biện pháp phòng trừ bệnh trên trái cam hiện nay chủ yếu dựa vào thuốc hóa học, dẫn đến tồn dư thuốc trên trái cây, ô nhiếm môi trường và gây độc cho con người. Một trong các phương pháp thay thế giúp giảm sử dụng thuốc hóa học là sử dụng dịch trích thực vật. Nghiên cứu này đã được thưc hiện để đánh giá hiệu quả in vivo của dịch trích ở nồng độ $6 \%$ của neem hoặc lược vàng đối với A. niger và Colletotrichum sp. Các trái cam đã lây nhiễm nhân tạo tác nhân gây thối trái thì được nhúng vào dịch trích ở nồng độ 6\% của neem hoặc lược vàng trong 30 giây, và giữ đến 11 ngày để ghi nhận chiều dài vết bệnh ở nhiệt độ phòng. Cái trái cam được nhúng vào nước cất thì dùng như nghiệm thức đối chứng. Kết quả cho thấy ở 11 ngày sau khi chủng bệnh, dịch trích neem và lược vàng làm giảm đáng kể vết thối Aspergillus lần lượt là 109,08 và 124,00 mm. Bên cạnh đó, vết bệnh thán thư trên trái cam đã bị ức chế có ý nghĩa thống kê bởi các dịch trích neem và lược vàng, với đường kính trung bình các vết bệnh lần lượt là 160,00 và 154,75mm, ở ngày 11 của thí nghiệm. Kết quả của nghiên cứu này đã chỉ ra rằng dịch trích neem và lược vàng ở nồng độ $6 \%$ có thể sử dụng như một biện pháp thay thế tự nhiên trong việc phòng trừ sự phát triển của tác nhân gây thối trái cam. Các loại dịch trích này có tương lai trong bảo vệ thực vật hiện đại, thay thế các loại thuốc hóa học tổng hợp truyền thống trong hệ sinh thái nông nghiệp.
\end{abstract}

Keywords: Aspergillus niger, Colletotrichum sp., leaf extract, orange fruit

\section{Introduction}

Nowadays, control of post-harvest disease of fruits is mainly implemented by usage of chemicals. In a research of Brown and Chambers (1999), the authors showed that application of aqueous polyhexamethylene biguanide solution to mandarins and oranges effectively managed green mold caused by Penicillium digitatum, sour rot caused by Geotrichum citri aurantii and stem-end-rot caused by Botryodiplodia theobromae. Stenzel et al. (1998) indicated that a fungicide of amide carbamates group had antifungal activity against Plasmopara viticola causing downy mildew in grapevine. Immersing oranges fruits into solutions of sodium molybdate at a concentration of 24.2 $\mathrm{mM}$ for $150 \mathrm{~s}$, or $1 \mathrm{mM}$ ammonium molybdate at 48 or $53^{\circ} \mathrm{C}$ provided effective control of green and blue molds caused by Penicillium spp. (Palou et al., 2002). An application of sorbitol liquid retarded the softening of flesh tissue, leading to inhibit an infection by Aspergillus niger (Kumpoun et al., 2003). Oliveira et al. (2000) showed that orange fruits which immersed for $1 \mathrm{~min}$ in aqueous suspensions of 
imazalil (100 $\mathrm{mg} \mathrm{l}^{-1}$ ) or thibendazole (1000 $\left.\mathrm{mg} \mathrm{l}^{-1}\right)$ and surfactant $(0 / 002 \%)$ could inhibit the growth of fungal pathogens. The persistence of fungicides might depend on the nature of fruits, concentrations of fungicides applied and storage conditions. Remained residues of harmful chemicals in fruits always affect consumers' health (Mohammadifar et al., 2012; Hue and Nghiem, 2014).

Based on this context, alternative safe treatments are investigated to manage fruit diseases. Among them, an application of plant extracts is promising due to their antifungal compounds including alkaloids, polyphenols, phenolic acid, flavonoids, quinones, flavones, flavonols, tannins, coumarins, polypeptides and terpenoids (Talibi et al., 2011; Gurjar et al., 2012; Chanh and Jin, 2014). Numerous plant species containing compounds with antimicrobial properties have been screened to manage diseases in many kinds of fruits. Most of these studies provide results of in vitro experiments, aimed at assessing the effect on conidial germination and mycelial growth of fungal pathogens causing fruit diseases (Islam et al., 2003). Only a few reports indicate the effectiveness of natural plant extracts in controlling the fruit diseases in vitro. Application of Mentha arvensis and Eugenia caryophyllata extracts reduced blue mold rot caused by $P$. italicum in orange and lime fruits, and enhanced their shelf life by 6 to 8 days (Tripathi et al., 2004; Sukorini et al., 2013). Aqueous extracts of Vitex negundo var. purpurescens at a concentration of $10 \%(\mathrm{~W} / \mathrm{V})$ offered the protection to carrots against Cladosporium, Fusarium and Geotrichum rot (Prakasam et al., 2001). Extracts of Solanum torvum were reported to be more effective in controlling the banana anthracnose disease caused by Colletotrichum musae. Furthermore, an increase in shelflife by 16 to 20 days over control was the additional benefit of treatment with an extract of S. torvum (Thangavelu et al., 2004). Aman and Rai (2015) reported that at in vitro studies, plant extracts of Garcinia cambogia Gaertn, Orthosiphon diffuses Benth and Radermachera xylocarpa Roxb had significantly antifungal activity against fungal growth and spore germination of Mycosphaerrella musicola on banana plants. Falade (2017) showed that Datura stramonium was the most effective extract, followed by Ricinus communis and Jatropha gossypifolia, on reducing hyphal growth rates of Colletotrichum lindemuthianum. However, these extracts had no significant inhibitory efficacy on conidial germination and sporulation in vitro.

In a research of Hidangmayum and Singh (2017), these authors showed that the extracts of Eupatorium birmanicum and Vitex negundo, both at a concentration of $20 \%(\mathrm{w} / \mathrm{v})$ had high inhibition rate of the fungus $A$. niger of pineapples in vitro. Fungicidal activity was also highly exhibited by Azadirachta indica extract at 100\% (w/v) against A. niger Van Tiegh, Fusarium oxysporum Schlecht, Geotrichum candidum Link and Rhizopus stolonifer Ehrenb ex. Fr. which isolated from tomato (Ngegba et al., 2018).

Management of Alternaria alternata causing fruit rot of strawberry was conducted by Patil and Suryawanshi
(2018). The results showed that the extracts of Zingiber officinale Rosc, Mimusops elengi L., Aloe vera L., Lantana camara L., Mentha arvensis Benth, Catharanthus roseus L., Eucalyptus globulus Labill, Allium sativum L., Calotropis gigantea (L.) R. Br. Ex Schult and Cymbopogon citrate DC Stapf at concentrations of 25, 50, 75 and 100\% (w/v) gave good control efficacy of rot lesions on strawberry fruits. On mango fruits, the aqueous extract of garlic (A. sativum) at a concentration of $100 \%(w / v)$ had inhibitory effect against Lasiodiplodia theobromae in vitro. This garlic extract could prevent Lasiodiplodia lesion development on mango fruits after soaking the fruits into the extracts for 4 hours (Nur Fatimma et al., 2018).

Citrus (Citrus spp.) is a valuable fruit widely cultivated in Viet Nam. A research of Xuyen (2012) showed that there were six kinds of post-harvest fungi of orange fruits in Viet Nam. Among them, A. niger and Colletotrichum sp. could cause rapid and severe damage on orange fruits (Xuyen, 2012). Moreover, Aspergillus fungi could secrete mycotoxins that severely affect human health (Ploetz, 2003). Farmers require an eco-friendly approach for managing Aspergillus rot and anthracnose on orange fruits. Utilization of ecofriendly botanical extracts has recently started to get characterized. Many kinds of botanical extracts were reported as biocontrol agents to control fruit rot pathogens in vitro conditions. However, the botanical extract potential at in vivo conditions is still insufficiently exploited on orange fruits due to deficiency of studies on this subject. Therefore, this study was carried out to evaluate the efficacy of extracts from neem and basket plants on inhibiting lesions of $A$. niger and Colletotrichum sp. on orange fruits.

\section{Materials and methods}

\subsection{Materials}

Fungal pathogens including A. niger and Colletotrichum sp. were obtained from Department of Plant Protection, College of Agriculture and Applied Biology, Can Tho University. These fungi were cultured on petri dishes of Potato Dextrose Agar medium at approximately 10-12 days before conducting experiments. Medium of Potato Dextrose Agar was prepared followed a procedure of Atlas (2004).

Fresh mature leaves of neem ( $A$. indica) and basket plant (Callisia fragrans) were collected at a garden of Department of Plant Protection, Can Tho University. These two kinds of plant were chosen due to their high ability to manage foliar diseases including blast, brown spot and bacterial leaf blight in rice plants (Thuy and Phuoc, 2015; other unpublished data). The leaves were washed thoroughly two times in tap water and then with sterile distilled water for one time, air-dried at room temperature, weighed at $6 \mathrm{~g}$ and ground with $100 \mathrm{~mL}$ sterile distilled water in a set of sterile mortar and pestle. The macerate was filtered with three folds of cheese cloth. 


\subsection{Assessment of leaf extract efficacy on orange fruits}

The experiment was carried out in completely randomized design, with three treatments including neem leaf extract, basket plant extract and a control treatment; with 12 replications, one orange fruit per one replication, four inoculated points per one fruit. Different aqueous concentrations of neem and basket plant extracts were screened in vitro conditions (data not shown). Based on these results, concentrations of neem extract at $6 \%(\mathrm{w} / \mathrm{v})$ and of basket plant extract at $6 \%(\mathrm{w} / \mathrm{v})$ were chosen to conduct experiments on orange fruits.

In the experiment, orange fruits were similar on size and color. The fruits were washed on tap water for two times, air-dried at room temperature approximately $30 \mathrm{~min}$, sprayed by ethanol at a concentration of $70 \%(\mathrm{~V} / \mathrm{V})$. A bunch of 4 sterile needles was used to create tiny holes with a depth of $4 \mathrm{~mm}$ on fruit epidermis. An orange fruit was inoculated at 4 positions. After 30 minutes, $1 \mathrm{~mL}$ of the spore suspension at a density of $10^{6}$ spore $\mathrm{mL}^{-1}$ was dropped on tiny holes on fruit surface. The inoculated orange fruits were put in an incubation chamber at $25^{\circ} \mathrm{C}$, with relative air humidity approximately $98 \%$ for $24 \mathrm{~h}$. After that, the inoculated orange fruits were immersed in the leaf extracts approximately $30 \mathrm{~s}$. On the untreated control, the fruits were handled identically, but sterile distilled water was used instead of the leaf extract. Finally, each inoculated fruit was kept in a transparent nilong bag, amenmend with wet cotton, at room temperature.
Lesion diameter on orange fruits were recorded at 3, 7 and 11 days after inoculation (DAl). The experiment was performed twice on each kind of fungal rot pathogen.

\subsection{Statistical analysis}

The data was analyzed using the Excel software (Microsoft Office Excel, 2010). Interpretations using an analysis of variance and Duncan's multiple range test at $p=0.05$ were performed with SPSS 16.0 software (IBM, USA).

\section{Results and discussion}

\subsection{Leaf extract efficacy on orange fruits inoculated with Aspergillus niger}

The leaf extract was treated one day after pathogen inoculation. The results showed that treatments of leaf extract had the ability to inhibit the lesion development caused by A. niger on orange fruit epidermis. However, their ability varied and depended on the kind of leaf extracts.

Disease incidence on orange fruits was 100\% (data not shown). At 3 DAl, lesion diameters of treatments of neem extract at a concentration of $6 \%$ and basket plant extract at a concentration of $6 \%$ were 51.33 and $55.50 \mathrm{~mm}$, respectively, significantly lower than the control one at approximately $69.08 \mathrm{~mm}$. On the next observations at 7 and 11 DAl, two treatments of leaf extract continued to inhibit lesion development on orange fruit surface, and significantly different to those of the control treatment. Efficacy of neem extract was better than one of basket plant extract (Table 1 and Figure 1).

\section{Table 1. Lesion diameter ( $\mathrm{mm}$ ) of rot lesions caused by A. niger on orange fruits}

Treatment

Neem leaf extract of $6 \%$

Basket plant extract of $6 \%$

Control with distilled water

Significance

CV (\%)

$3^{1 /}$
$51.33 \pm 6.4^{\mathrm{b}}$
$55.50 \pm 5.9^{\mathrm{b}}$
$69.08 \pm 6.7^{\mathrm{a}}$
$\star$

18.21
Days after inoculation

$7^{1 /} \quad 11^{1 /}$

$80.25 \pm 8.2^{b c}$

$109.08 \pm 9.3^{b c}$

$92.67 \pm 8.5^{b}$

$124.00 \pm 9.3^{b}$

$120.58 \pm 9.8^{a}$

22.13
$170.92 \pm 8.3^{a}$

*

17.64

\footnotetext{
"Mean \pm SE (standard error) followed by the same letter do not differ significantly according to Duncan's multiple range test at $p \leq$ 0.05. *: significant at $p \leq 0.05$
} 


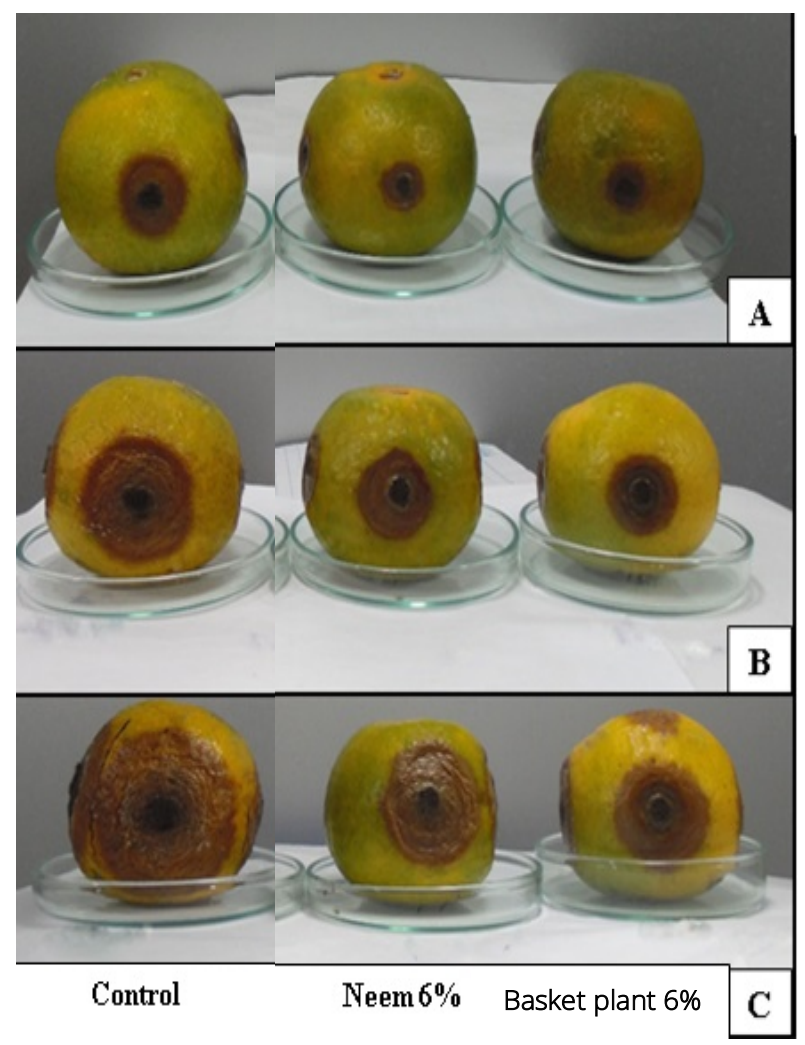

Figure 1. Efficacy of leaf extracts on lesions' development caused by $A$. niger on orange fruits at 3 days (A), 7 days (B) and 11 days $(C)$.
The orange fruits were wounded on epidermis at four various positions by sterile needles and inoculated with Aspergillus spore suspension at a density of $10^{6}$ spore $\mathrm{mL}^{-1}$. After that, these fruits were treated with solutions of leaf extracts. Control: orange fruit was treated with distilled water, Neem 6\%: the orange fruit was treated with neem leaf extract at a concentration of 6\%; Basket plant 6\%: the orange fruit was treated with basket plant extract at a concentration of $6 \%$.

\subsection{Leaf extract efficacy on orange fruits inoculated with Colletotrichum sp.}

Both extract treatments inhibited Colletotrichum lesions on orange fruits. Therefore, they had high ability on controlling the anthracnose disease in oranges.

Disease incidence on orange fruits was 100\% (data not shown). During three observation times at 3, 7 and 11 DAl, lesion diameter of neem and basket plant extract treatments varied approximately 29-38, 72-79, and 154-160 $\mathrm{mm}$, respectively, significantly lower than those of the control treatment (Table 2 and Figure 2).

Table 2. Anthracnose lesion diameter $(\mathrm{mm})$ caused by Colletotrichum $\mathrm{sp}$. on orange fruits

Treatment

Neem leaf extract of $6 \%$

Basket plant extract of $6 \%$

Control with distilled water

Significance

CV (\%)

$3^{1 /}$
$29.08 \pm 4.2^{\mathrm{b}}$
$38.00 \pm 3.7^{\mathrm{b}}$
$58.33 \pm 4.1^{\mathrm{a}}$
$\star^{*}$

30.32
Days after inoculation

$\begin{array}{cc}7^{1 /} & 11^{1 /} \\ 79.00 \pm 6.3^{\mathrm{b}} & 160.00 \pm 10.5^{\mathrm{b}} \\ 72.17 \pm 7.2^{\mathrm{b}} & 154.75 \pm 11.4^{\mathrm{b}} \\ 119.00 \pm 8.0^{\mathrm{a}} & 209.67 \pm 12.6^{\mathrm{a}} \\ \star & * \\ 26.76 & 14.83\end{array}$

\footnotetext{
"Mean \pm SE (standard error) followed by the same letter do not differ significantly according to Duncan's multiple range test at $p \leq$ 0.05. *: significant at $p \leq 0.05$
}

The orange fruits were wounded on epidermis at four various positions by sterile needles and inoculated with Colletotrichum spore suspension at a density of $10^{6}$ spore $\mathrm{mL}^{-1}$. After that, these fruits were treated with solutions of leaf extracts. Control: orange fruit was treated with distilled water, Neem 6\%: the orange fruit was treated with neem leaf extract at a concentration of 6\%; Basket plant 6\%: the orange fruit was treated with Basket plant extract at a concentration of $6 \%$.

Many plant extracts have been reported as having antimicrobial activities against fruit rot pathogens. The aim of the presented study was to elucidate the effect of two botanical extracts as an alternative to synthetic fungicides in controlling lesion development of $A$. niger and Colletotrichum sp. on orange fruits. Our results indicated that both tested leaf extracts of neem and basket plant caused a significant reduction in the length of rot lesions.
Similar efficacy of neem extracts effectively against fungal fruit pathogens was reported by several authors. Efficacy of neem extract at concentrations of 5, 10, 15 and 20\% against $A$. niger were 78.12, 72.00, 65.36 and 54.00\%, respectively, on pineapple fruits (Hidangmayum and Singh, 2017). The percentage of treatment efficacy on orange fruits against $A$. niger in our study was approximately 23$36 \%$, lower than the efficacy on pineapple. The extract of neem could inhibit the development of hyphal growth of Penicillium digitatum in vitro (Al-Samarrai et al., 2012) as well as reduce fruit rot in vivo (Nath et al., 2013). Efficacy of the neem extract on inhibiting fungal growth was also reported on tomato (Nashwa and Abo-Elyousr, 2012; Ngegba et al., 2018). In this study, extract of basket plant had efficacy on inhibiting the development of rot lesions of both A. niger and Colletotrichum sp., but lower than those of the neem extract. Studies of application of the extract of basket plant on fruit rot pathogens have not been carried out. 


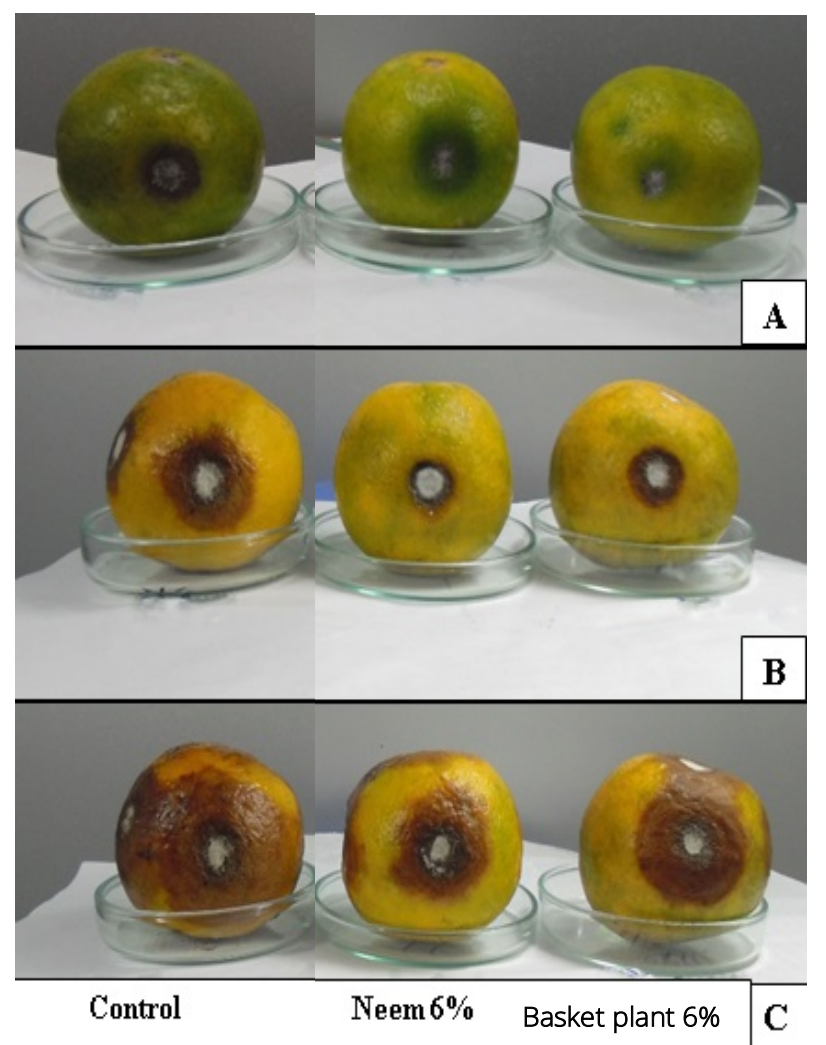

Figure 2. Efficacy of leaf extracts on anthracnose lesions' development caused by Colletotrichum sp. on orange fruits at 3 days (A), 7 days (B) and 11 days (C).

Plant extracts including neem and basket plant are an important source of natural agrochemicals which are environmentally friendly and do not have any toxic effects on fruits. They possess fungicidal properties. A research of Cowan (1999) indicated that natural extracts from plants contain many kinds of phytochemicals, most of which are polyphenols or oxygen-substituted derivatives. Other important compounds are phenolic acids, quinones, flavones, flavonols, tannins, coumarins and polypeptides (Cowan, 1999; Gurjar et al., 2012). Water is a universal solvent which is used to do plant extracts easily and this solvent is safe to fruit peels. Water is found to be the best solvent for the extraction of phenolic compounds, tannins, saponins and terpenoids (Gurjar et al., 2012). Phenolic compound, phenolic acids and terpenoids could degrade fungal cell walls, leading to membrane disruption. Tannins bind to proteins, leading to enzyme inhibition inside fungal cells. The bio-components of extracts from neem and basket plant have not fully revealed.

\section{Conclusion}

This study had shown that the neem and basket plant extracts, both at a concentration of $6 \%$, have the potentials in the protection of orange fruit rots caused by $A$. niger and Collettrichum sp. Therefore, due to the fact that chemical control of fruit rot is hazardous to human health and environmental, this biodegradable, non-toxic extract could be used as an alternative and green approach on reducing and controlling fruit rot of oranges. Formulation of these extracts will be studied on the further researches.

\section{References}

[1] Al-Samarrai, G., Singh, H., Syarhabil, M. 2012. Evaluating eco-friendly botanical (natural plant extracts) as alternatives to synthetic fungicides. Annals of Agricultural and Environmental Medicine 19(4): 673-676.

[2] Aman, M., Rai, V.R. 2015. Antifungal activity of fungicides and plant extracts against yellow sigatoka disease causing Mycosphaerella musicola. Current Research in Environmental and Applied Mycology 5(3): 277-284.

[3] Atlas, R.M. 2004. Handbook of microbiological media, 3rd edition. CRC Press Boca Raton London New York Washington, D.C. 2051 p.

[4] Brown, G.E., Chambers, M. 1999. Evaluation of polyhexamethylene biguanide for control of postharvest diseases of Florida citrus. Proceedings of the 112th Annual Meeting of the Florida State Horticultural Society 112: 118-121.

[5] Chanh, N.D.M., Jin, J.W. 2014. Nematicidal properties of crude extracts obtained from medicinal plants against root-lesion nematode Pratylenchus coffeae. Journal of Vietnamese Environment 6(3): 264-269.

[6] Cowan, M.M. 1999. Plants products as antimicrobial agents. Clinical Microbiology Reviews 12(4): 564-682.

[7] Falade, M.J. 2017. In vitro evaluation of antifungal activities for six plant extracts against Colletotrichum lindemuthianum Sensu-lato. American Journal of Plant Biology 2(2): 61-65.

[8] Gurjar, M.S., Ali, S., Akhtar, M., Singh, K.S. 2012. Efficacy of plant extracts in plant disease management. Agricultural Sciences 3(3): 425-433.

[9] Hidangmayum, B., Singh, N.I. 2017. Efficacy of plant extracts on fruit rot pathogen of pineapple (Ananas comosus Merr.). International Journal of Engineering Development and Research 5(4): 1353-1355.

[10] Hue, N.T., Nghiem, H.D. 2014. Research on the status of chemical pesticide uses in agricultural activities in Phan Me commune, Phu Luong district, Thai Nguyen province. Journal of Vietnamese Environment 6(2): 138-141.

[11] Islam, M.R., Alam, S., Rahman, M.Z., Chowdhury, S.P., Begum, M.F., Akhter, M., Alam, M.S., Han, K.D., Lee, M.W. 2003. Effects of plant extracts on conidial germination, mycelial growth and sporulation of fungi isolated from poultry feed. The Korean Society of Mycology 31(4): 221-225.

[12] Kumpoun, W., Motomura, Y., Harada, Y. 2003. Inhibition of Aspergillus rot by sorbitol in apple fruit with watercore symptoms. Postharvest Biology and Technology 29:121-127. 
[13] Mohammadifar, M., Norabadi, M.T., Hasanzadeh, M., Dashtipoor, S., Etebarian, H.R., Sahebani, N. 2012. Study of antifungal activities of seven essential oils from some Iranian medicinal plants against various postharvest phytopathogenic fungi. Archives of Phytopathology and Plant Protection 45(17): 2046-2056.

[14] Nashwa, S.M.A, Abo-Elyousr, K.A.M. 2012. Evaluation of various plant extracts against the early blight disease of tomato plants under greenhouse and field conditions. Plant Protection Science 48(2): 74-79.

[15] Nath, A., Barman, K., Chandra, S., Baiswar, P. 2013. Effect of plant extracts on quality of Khasi mandarin (Citrus reticulata Blanco) fruits during ambient storage. Food Bioprocess Technology 6(2): 470-474.

[16] Ngegba, P.M., Kanneh, S.M., Bayon, M.S., Ndoko, E.J., Musa, P.D. 2018. Fungicidal effect of three plants extracts in control of four phytopathogenic fungi of tomato (Lycopersicum esculentum L.) fruit rot. International Journal of Environment, Agriculture and Biotechnology 3(1): 112-117.

[17] Nur Fatimma, A., Munirah, M.S., Sharifah Siti Maryam, S.A.R., Najihah, A., Nur Ain Izzati, M.Z. 2018. Efficacy of Allium sativum extract as post-harvest treatment of fruit rot of mango. Plant Pathology and Quarantine 8(2): 144-152.

[18] Oliveira, J.J.V., Toledo, M.C.F. 2000. Residue levels of thiabendazole and imazalil in orange fruit (Citrus sinensis ( $L$ ) Osbeck cv. Pêra) after treatment by dipping in postharvest. Revista Brasileira de Fruiticultura 22: 339-344.

[19] Palou, L., Usall, J., Smilanick, J.L., Aguilar, M.J., Viñas, I. 2002. Evaluation of food additives and low toxicity compounds as alternative chemicals for the control of Penicillium digitatum and Penicillium italicum. Pest Management Science 58: 459-466.

[20] Patil, J.S., Suryawanshi, N.S. 2015. Management of A/ternaria alternata causing fruit rot of strawberry using plant extracts. International Journal of Life Sciences, special issue: $42-46$.
[21] Ploetz, R.C. 2003. Diseases of Tropical Fruit Crop. University of Florida, IFAS, Tropical Research and Education Center Homestead, Florida, USA. 527p.

[22] Prakasam, V., Abraham, S., Kannan, C. 2001. Management of postharvest fungal diseases of carrot using botanicals. South Indian Horticulture 49: 271-274.

[23] Stenzel, K., Pontzen, R., Seitz, T., Tiemann, R., Witzenberger, A. 1998. SZX 722: a novel systemic oomycete fungicide. Pests and Diseases 2: 367-374.

[24] Sukorini, H., Sangchote, S., Khewkhom, N. 2013. Plant crude extracts and yeasts as alternative to synthetic fungicide for controlling postharvest green mould on citrus fruit. Acta Universitatis Agriculturae et Silviculturae Mendelianae Brunensis 88(3): 795-801.

[25] Talibi, I., Askarne, L., Boubaker, H., Boudyach, E.H., Msanda, F., Saadi, B., Aoumar, A.A.B. 2011. Antifungal activity of some Moroccan plants against Geotrichum candidum, the causal agent of postharvest citrus sour rot. Journal of Crop Protection 35: 41-46.

[26] Thangavelu, P., Sundaraju, P., Sathiamoorthi, S. 2004. Management of anthracnose disease of banana caused by Colletorichum musae using plant extracts. Journal of Horticultural Science and Biotechnology 79: 664-668.

[27] Thuy, T.T.T., Phuoc, N.V. 2015. Ability of plant extracts from Ageratum conyzoides and Azadirachta indica on induced resistance against rice blast. Journal of Vietnamese Plant Protection 4(261): 25-28.

[28] Tripathi, P., Dubey, N.K., Banerji, R., Chansouria, J.P.N. 2004. Evaluation of some essential oils as botanical fungitoxicants in management of postharvest rotting of citrus fruits. World Journal of Microbiology and Biotechnology 20: 317-321.

[29] Xuyen, N.T.M. 2012. Diagnostic on post-harvest fungal pathogens on orange 'Sanh' (Citrus nobilis var. typica Hassk) and mandarin 'Duong' (Citrus reticulata Blanco). Thesis on Plant Protection, Can Tho University. $55 p$. 